\title{
PROGAM PENGABDIAN MASYARAKAT: PENINGKATAN KETERAMPILAN MENYAJIKAN PRESENTASI MENARIK DAN INTERAKTIF BAGI GURU PKBM NEGERI 27 PETUKANGAN DENGAN PELATIHAN MICROSOFT POWER POINT
}

\author{
Safitri Juanita $^{\text {(), Putri Hayati }}{ }^{2)}$ dan Dolly Virgian Shaka Yudha Sakti ${ }^{3)}$ \\ ${ }^{1}$ Sistem Informasi, Fakultas Teknologi Informasi, Universitas Budi Luhur \\ ${ }^{2,3}$ Teknik Informatika, Fakultas Teknologi Informasi, Universitas Budi Luhur \\ 1,2,3 Jl. Ciledug Raya, RT.10/RW.2, Petukangan Utara, Pesanggrahan, Jakarta Selatan, DKI Jakarta 12260 \\ E-mail : safitri.juanita@budiluhur.ac.id ${ }^{1)}$, putri.hayati@budiluhur.ac.id ${ }^{2}$, dolly.virgianshaka@budiluhur.ac.id ${ }^{3)}$
}

\begin{abstract}
ABSTRAK
PKBM Negeri 27 Petukangan adalah salah satu pendidikan nonformal yang menjadi wadah pembelajaran dan pemberdayaan masyarakat yang memiliki kegiatan PAUD, program pendidikan kesetaraan (Paket A, Paket B, Paket C) dan pendidikan keterampilan yang berlokasi di Jakarta Selatan. Dalam kegiatan belajar mengajar diperlukan keterampilan bagi guru untuk menyajikan materi pelajaran kepada siswa dengan tampilan interaktif dan menarik supaya siswa dapat lebih memahami pelajaran yang diberikan oleh guru. Namun saat ini guru kurang menguasai Microsoft Power Point dan mitra tidak memiliki tenaga pelatih yang menguasai aplikasi komputer serta belum memiliki fasilitas komputer untuk mengadakan pelatihan komputer. Tujuan kegiatan Pengabdian Kepada Masyarakat (PKM) ini adalah memberikan pengetahuan dan keterampilan kepada guru cara membuat presentasi bahan ajar lebih menarik dan interaktif bagi siswa dan meningkatkan hubungan dan kerjasama antara Universitas Budi Luhur dengan PKBM sebagai mitra. Metode yang digunakan adalah survey, wawancara, pemberian materi dan praktikum serta menyebarkan kuesioner sebagai feedback dari mitra dan evaluasi kegiatan PKM. Kesimpulan dari kegiatan ini menunjukkan bahwa kegiatan pelatihan penggunaan aplikasi presentasi dengan Microsoft Power Point berjalan dengan baik dan terbukti meningkatkan keterampilan guru di PKBM Negeri 27 Petukangan ini terbukti dengan adanya hasil evaluasi kegiatan yang menunjukkan bahwa 50\% menyatakan setuju isi materi pelatihan jelas dan mudah dipahami, 62\% sangat setuju contoh latihan jelas dan mudah dipahami, 50\% menyatakan setuju instruktur dan asisten instruktur membantu peserta memahami materi dengan baik, 50\% menyatakan sangat setuju fasilitas laboratorium komputer sesuai dengan kebutuhan.
\end{abstract}

Kata Kunci: PKBM 27, Pelatihan Komputer, Materi Pelajaran, Microsoft PowerPoint, Keterampilan Guru

\section{PENDAHULUAN}

Kebutuhan menyajikan proses belajar interaktif, inspiratif, menyenangkan, menantang, memotivasi peserta didik untuk berpartisipasi aktif, serta memberikan ruang yang cukup bagi prakasa, kreativitas, dan kemandirian sesuai dengan bakat, minat, dan perkembangan fisik serta psikologis peserta didik tertuang pada Peraturan Pemerintah nomor 19 tahun 2005 pasal 19 Ayat 2, sedangkan Pasal 40 ayat 2 Undang Undang nomor 20 tahun 2003 dinyatakan bahwa pendidik dan tenaga pendidik berkewajiban menciptakan suasana pendidikan yang bermakna, menyenangkan, kreatif, dinamis, dan dialogis (Harmanto, 2015).

Dengan mengetahui peraturan dan perundangundangan tersebut sangat jelas bahwa dalam proses belajar mengajar sangat diperlukan seorang pendidik yang berkualitas tinggi yang bisa menggunakan berbagai metode yang menarik dan menciptakan suasana pembelajaran yang adaptif sesuai dengan kebutuhan peserta secara umum (Harmanto, 2015).
Seorang pendidik memerlukan media pembelajaran yaitu alat yang dapat membantu proses belajar mengajar sehingga makna pesan yang disampaikan menjadi lebih jelas dan tujuan pendidikan atau pembelajaran dapat tercapai dengan efektif dan efisien (Nurrita, 2018).

Manfaat media pembelajaran menurut (Nurrita, 2018) yaitu: (1) memberikan pedoman guru untuk mencapai tujuan pembelajaran sehingga dapat menjelaskan materi pembelajaran dengan urutan sistematis dan membantu dalam penyajian materi menarik untuk meningkatkan kualitas pembelajaran. (2) meningkatkan motivasi dan minat belajar siswa sehingga dapat berpikir dan menganalisis materi pelajaran yang diberikan guru dengan baik dengan situasi belajar yang menyenangkan dan dapat memahami pelajaran dengan mudah.

Pentingnya pengembangan media belajar dijelaskan pula pada laman kemendikbud.go.id (Kemdikbud, 2019) bahwa Mendikbud Bapak Muhadjir menggarisbawahi peran pengembang teknologi 
pembelajaran (PTP) dalam mendukung pendidikan di Indonesia meliputi: 1. mengembangkan model teknologi pembelajaran; 2. mengembangkan media pembelajaran berbasis TIK; 3. mengembangkan model aplikasi yang menunjang pembelajaran yang inovatif dan kreatif; dan 4. mengoptimalkan peran Rumah Belajar.

Pentingnya pelatihan penguasaan teknologi informasi dan manfaatnya bagi masyarakat terutama peningkatan kompetensi Guru dapat diketahui pada jurnal-jurnal kegiatan PKM yang telah dilakukan sebelumnya, seperti jurnal PKM dengan judul "IBM untuk Peningkatan Kompetensi Guru dalam penggunaan Aplikasi Komputer di Bandar Lampung" (Fitria and Arfida, 2015) kegiatan PKM yang dilakukan adalah pelatihan penggunaan Microsoft Word, Excel dan Power Point. Kesimpulan dari kegiatan ini adalah guru dapat menguasai aplikasi office dengan baik dan dapat meningkatkan mutu pembelajaran bagi guru.

Jurnal PKM lain berjudul "Perangkat Lunak Powerpoint untuk Meningkatkan Kinerja Guru di SD dan SMP 19 Muhammadiyah Sawangan Depok" (Shedriko, Setiawan and Kusmayadi, 2018) menjelaskan bahwa kegiatan PKM bertujuan memberikan pelatihan powerpoint secara umum, pengenalan fitur-fitur dan penggunaanya dalam pembuatan suatu file Powerpoint yang dapat memberikan nilai tambah dalam penyampaian bahan ajar. Dalam penyampaiannya, peserta dikelompokkan dalam dua kelompok. Kelompok pertama adalah kelompok yang terdiri dari guru-guru SMP 19 Muhammadiyah, sedangkan kelompok kedua adalah kelompok yang terdiri dari guru-guru SD Muhammadiyah. Kesimpulan dari kegiatan ini adalah Peserta merasakan nilai positif dari kegiatan pelatihan yang diselenggarakan dengan tujuan untuk membuat media pembelajaran yang interaktif ini.

Kegiatan PKM yang dipublikasikan pada prosiding SNP2M berjudul "PKM Service For Teachers Group In Improving Their Microsoft Office Skills At SMA Negeri 10 Makassar"'(Nahlah et al., 2018) program PKM ini memberikan pelatihan kepada guru di SMAN 10 Makassar yang belum memanfaatkan Microsoft office dalam proses belajar mengajar dan pengolahan administrasi. Pelatihan yang diberikan adalah pelatihan Microsoft Excel dan Power Point. Kesimpulan dari kegiatan ini adalah pelatihan komputer telah membuka wawasan peserta pelatihan akan manfaat dari materi yang diberikan.

Kegiatan PKM lainnya yang terpublikasi pada tahun 2018 berjudul "Peningkatan Kompetensi Mengajar Guru-Guru Paud Di Wilayah Kecamatan Blimbing Kota Malang Dengan Pelatihan Komputer Dan Multimedia" (Nurhadi, Santoso and Kasijanto, 2018) masalah yang ditemukan pada mitra PKM adalah sistem administrasi surat menyurat, sistem keuangan, dan lain-lain seringkali mengalami hambatan karena masih dilakukan secara manual, sehingga hasilnya kurang optimal. Peralatan multimedia LCD proyektor dan power point untuk presentasi belum dimanfaatkan dengan baik pada proses pembelajaran, sehingga pembelajaran kurang menyenangkan. Tujuan PKM adalah memberikan pengetahuan dan ketrampilan/skill komputer dan multimedia kepada Guru PAUD agar mampu memperbaiki sistem administrasi PAUD dan mengembangkan proses pembelajaran. Kesimpulannya bahwa kegiatan PKM berupa Pelatihan komputer dan mulimedia bagi Guru PAUD di wilayah Kec. Blimbing Kota Malang dapat meningkatkan pengetahuan dan skill Guru PAUD untuk memamfaatkan teknologi komputer dan multimedia dalam pembelajaran sehingga memudahkan proses pembelajaran dan pengelolaan PAUD.

Jurnal PKM lainnya pada tahun 2019 berjudul "Pembinaan Pemanfaatan Teknologi Informasi Dan Komunikasi Pada Masyarakat Pulau Temoyong Batam Kepulauan Riau" (Simanjuntak and Handoko, 2019) yang dilakukan pada kegiatan PKM adalah pembinaan mengenai pengantar teknologi informasi dan komunikasi kepada masyrakat Pulau Temoyong, Kecamatan Bulang, Kota Batam, Kepulauan Riau ini. Dengan cara membimbing mereka dalam menggunakan aplikasi yang sering digunakan pada saat ini seperti menggunakan Microsoft Office dengan Word, Power Point dan Excel. Hasil dari kegiatan pembinaan ini menunjukkan bahwa para masyarakat pulau temoyong paham akan pemanfaatkan teknologi informasi dan komunikasi dan juga mengerti menggunakan Microsoft office, sehingga masyarakat bisa memanfaatkannya dengan baik

Kesimpulan dari publikasi kegiatan PKM yang telah dilakukan sebelumnya yaitu, dengan dilakukan pembinaan masyarakat berupa pelatihan komputer terutama aplikasi komputer Microsoft Office khususnya Microsoft Power Point memberikan manfaat bagi masyarakat terutama masyarakat yang berprofesi sebagai guru dalam meningkatkan mutu pembelajaran.

Mitra program Pengabdian Kepada Masyarakat ini adalah Pusat Kegiatan Belajar Masyarakat (PKBM) 27 Petukangan yaitu sekolah yang memiliki cakupan Wilayah 8 RW dan 9 RT. Data peserta didik PKBM 27 Petukangan Selatan pada tahun 2019 adalah Paket A = 123 orang, Paket $\mathrm{B}=1011$ org, Paket $\mathrm{C}=2019$.

Namun saat ini media belajar yang digunakan pada PKBM 27 Petukangan masih belum menggunakan teknologi informasi dengan memanfaatkan aplikasi komputer yang dapat membantu guru dalam menyajikan materi belajar menjadi lebih menarik dan interaktif. Hal ini tentu saja menjadi tantangan pihak sekolah untuk memotivasi guru-guru tersebut agar mulai belajar menguasai salah satu aplikasi komputer untuk presentasi salah satunya Microsoft Power Point..

Masalah yang ada pada PKBM 27 Petukangan adalah saat ini guru di PKBM 27 Petukangan kurang menguasai Microsoft Power Point dan PKBM 27 Petukangan tidak memiliki tenaga pelatih yang menguasai aplikasi komputer serta belum memiliki fasilitas komputer untuk mengadakan pelatihan komputer. 
Adapun solusi yang akan diberikan terhadap permasalah mitra PKM adalah : (1) memberikan narasumber pelatihan pembuatan presentasi menarik dan interaktif yaitu tim pengabdi yang merupakan dosen Universitas Budi Luhur yang memiliki kompetensi untuk membuat bahan ajar atau materi bagaimana cara membuat presentasi menarik dan interaktif dengan memanfaatkan teknologi informasi untuk membantu menyelesaikan masalah yang ada pada PKBM 27 Petukangan sebagai mitra pada program pengabdian kepada masyarakat (PKM). (2) Menyediakan fasilitas Laboratorium Komputer untuk mengadakan pelatihan aplikasi komputer dengan Microsoft Power Point.

Tujuan dari kegiatan PKM ini adalah guru-guru di PKBM 27 Petukangan dapat meningkatkan kemampuan dalam menguasai aplikasi presentasi materi atau bahan ajar dengan memanfaatkan teknologi informasi terutama aplikasi Microsoft Power Point sehingga materi yang disajikan kepada siswa lebih menarik dan interaktif.

\section{RUANG LINGKUP}

Kegiatan pengabdian kepada masyarakat ini bertujuan memberikan pengetahuan kepada guru di PKBM Negeri 27 Petukangan bagaiamana cara menggunakan Microsoft Power Point sehingga guru dapat membuat presentasi bahan ajar lebih menarik dan interaktif bagi siswa.

\section{BAHAN DAN METODE}

Langkah-langkah dari persiapan kegiatan PKM hingga laporan kegiatan PKM dilakukan selama 4 Bulan (April-Agustus 2019) dan tahapan kegiatan akan ditampilkan pada gambar 1 .

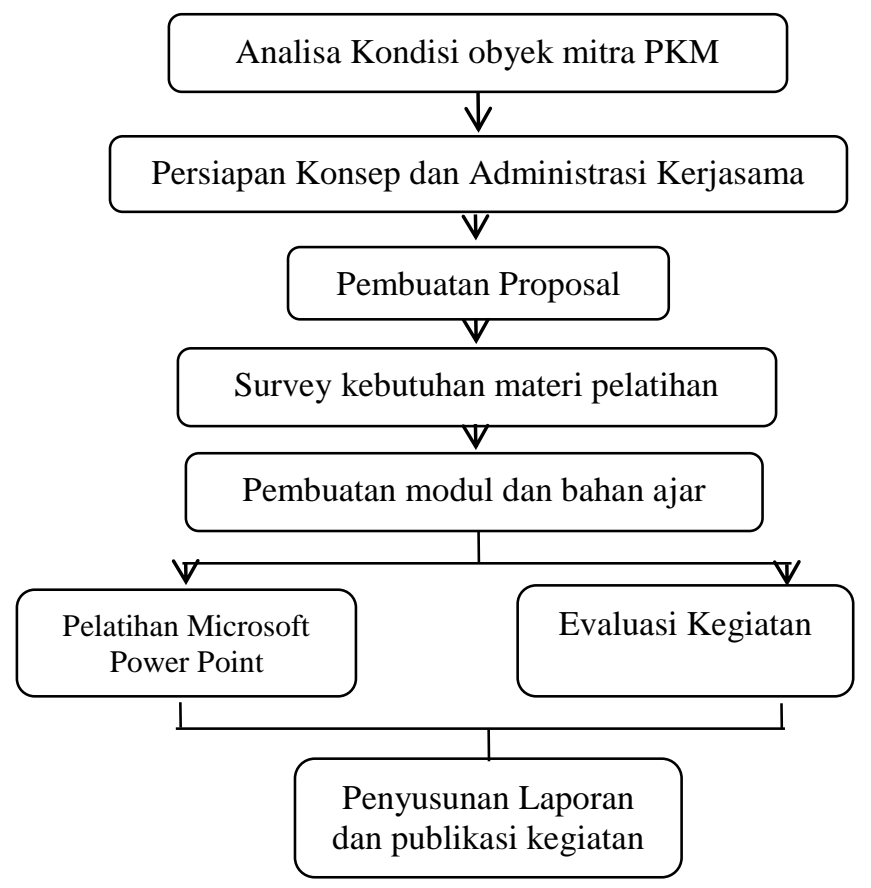

Gambar 1. Tahapan Kegiatan Pengabdian Kepada Masyarakat
Uraian kegiatan program pengabdian kepada masyarakat adalah sebagai berikut :

1. Analisa Kondisi Obyek Mitra Pengabdian Kepada Masyarakat: Survey atau wawancara dilakukan kepada mitra pengabdian kepada masyarakat yaitu pengurus Pusat Kegiatan Belajar Masyarakat (PKBM) Negeri 27 Petukangan yang akan menjadi target pelaksanaan program pengabdian masyarakat, guna mengetahui kebutuhan materi pelatihan yang diperlukan oleh peserta pelatihan.

2. Persiapan Konsep dan Administrasi Kerjasama: Koordinasi dan Persiapan kegiatan pengabdian kepada masyarakat dan pengajuan permohonan narasumber dari mitra kepada Universitas Budi Luhur.

3. Pembuatan Proposal: Membuat proposal kegiatan pengabdian kepada masyarakat sebagai salah satu syarat pengajuan dana hibah internal di Universitas Budi Luhur.

4. Survey kebutuhan materi pelatihan: Melakukan survey kebutuhan materi pelatihan dengan melakukan diskusi dengan mitra dan melakukan peminjaman laboratorium komputer di Universitas Budi Luhur.

5. Pembuatan modul dan bahan ajar : Membuat modul dan bahan ajar sesuai materi yang akan disampaikan kepada peserta pelatihan komputer "Peningkatan Keterampilan Menyajikan Presentasi Menarik dan Interaktif Bagi Guru PKBM Negeri 27 Petukangan dengan Pelatihan Microsoft Power Point"

6. Pelatihan penguasaan aplikasi komputer yaitu Microsoft Power Point. Tahapan ini akan dilakukan dengan 2 cara yaitu :

(1) Sosialisasi dengan memberikan ceramah, tanya jawab dan diskusi. Metode ceramah menurut (Sanjaya, 2014) dapat diartikan sebagai cara menyajikan pelajaran melalui penuturan secara lisan atau penjelasan langsung kepada sekelompok siswa, Diskusi menurut (Sagala, 2017) adalah percakapan ilmiah yang responsive berisikan pertukaran pendapat yang dijalin dengan pertanyaan problematic. (2) Pelatihan Komputer dilakukan dengan metode praktikum. Proses belajar mengajar dengan praktikum yang menurut (Sagala, 2017) berarti peserta diberi kesempatan untuk mengalami sendiri, mengikuti proses, mengamati suatu objek, menganalisis, membuktikan, dan menarik kesimpulan sendiri tentang suatu objek, keadaan, atau proses sesuatu. Materi pelatihan diberikan dalam bentuk softcopy dan hardcopy kepada peserta sehingga memudahkan peserta untuk mengikuti materi pelatihan dan dapat dijadikan sebagai bahan ajar oleh peserta.

7. Evaluasi Kegiatan: Memberikan kuesioner kepada peserta pelatihan komputer "Peningkatan Keterampilan Menyajikan Presentasi Menarik dan Interaktif Bagi Guru PKBM Negeri 27 Petukangan dengan Pelatihan Microsoft Power Point" untuk 
menerima feedback dari pelatihan yang telah dilakukan sehingga pelaksana pengabdian kepada masyarakat dapat melakukan perbaikan untuk pelatihan berikutnya.

8. Penyusunan Laporan kegiatan dan publikasi kegiatan.

\section{PEMBAHASAN}

Pada bab ini akan diuraikan tentang hasil kegiatan pengabdian kepada masyarakat (PKM), dokumentasi kegiatan PKM dan hasil evaluasi kegiatan PKM dalam bentuk grafik.

\subsection{Hasil Kegiatan}

Pada kegiatan PKM ini kami memberikan pelatihan kepada guru yang mengajar di PKBM 27 Petukangan Dari total rencana 30 orang peserta ternyata yang mendaftar 10 orang guru dan yang hadir saat pelatihan hanya 8 orang peserta dan seluruh peserta mengikuti pelatihan pengenalan lingkungan Microsoft Power Point 2010, latihan membuat presentasi menarik dan interaktif dengan animasi, audio, video dan link. Peserta berhasil melakukan semua latihan yang diberikan serta tugas yang diberikan saat pelatihan dan Peserta pelatihan dapat mengikuti semua rangkaian kegiatan praktikum dari pekan pertama sampai pekan kedua dengan baik.

\subsection{Dokumentasi Kegiatan Pengabdian}

Pada gambar 2, Dosen sebagai instruktur memberikan materi langkah-langkah cara membuat presentasi menarik dan interaktif dengan Microsoft Power Point. Pada sesi ini peserta diajarkan cara membuat dan menyimpan file presentasi, cara merubah desain template dan cara mengunduh template sesuai kebutuhan materi yang ingin ditampilkan, cara menambahkan gambar dan video.

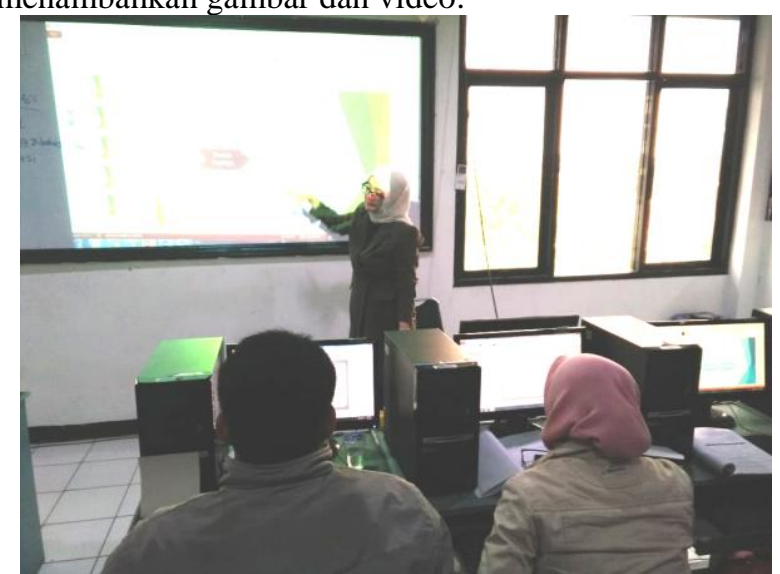

Gambar 2. Instruktur 1 memberikan materi pelatihan membuat presentasi menarik dan interaktif

Pada gambar 3, Dosen sebagai instruktur memberikan materi langkah-langkah membuat animasi dan transisi sehingga presentasi terlihat menarik dan interaktif dengan Microsoft Power Point. Pada sesi ini Dosen berbagi tips cara membuat presentasi menarik dan interaktif

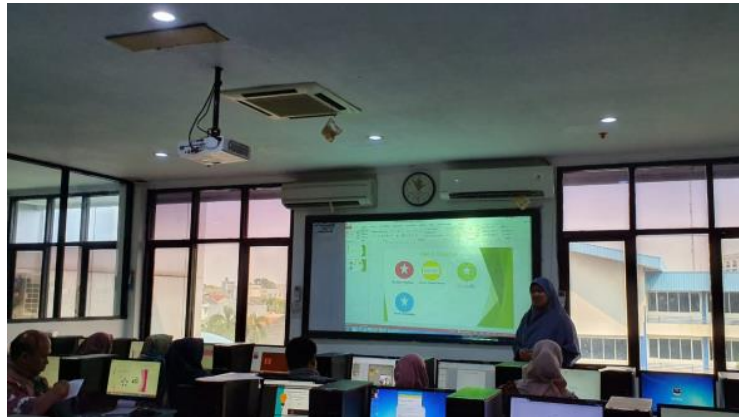

Gambar 3. Instruktur 2 memberikan materi membuat animasi dan tips dalam membuat presentasi

Pada gambar 4 tim pengabdi melibatkan mahasiswa aktif Universitas Budi Luhur sebagai Asisten instruktur (foto paling kanan) untuk membantu menyiapkan fasilitas laboratorim komputer sebelum kegiatan dimulai dan membantu mengatasi kendala teknis yang dialami oleh peserta program PKM saat berada di laboratorium Komputer dengan tujuan peserta dapat mengikuti pelatihan lebih maksimal.

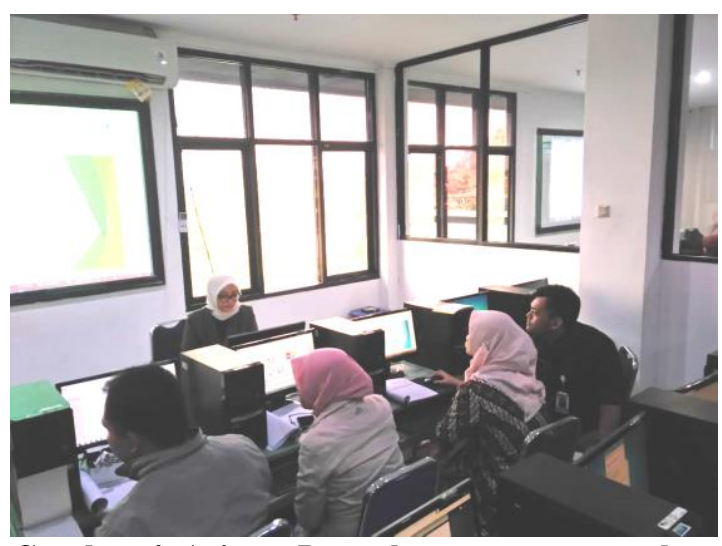

Gambar 4. Asisten Instruktur yang merupakan mahasiswa aktif membantu peserta pelatihan

Gambar 5 adalah dokumentasi foto bersama antara tim pengabdi program PKM yaitu Dosen Fakultas Teknologi Informasi (FTI) Universitas Budi Luhur, Jakarta dan Guru PKBM Negeri 27 Petukangan.

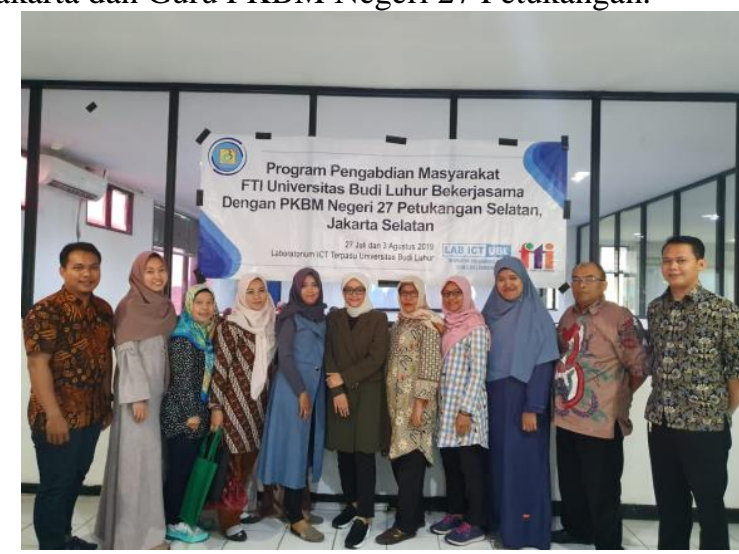

Gambar 5. Tim Pengabdi Program PKM dan Peserta pelatihan Komputer 


\subsection{Hasil Evaluasi Kegiatan Pengabdian}

Berikut adalah hasil evaluasi kegiatan PKM pelatihan aplikasi komputer Microsoft Power Point.

1. Isi Materi Pelatihan jelas dan mudah dipahami

Berdasarkan hasil kuesioner yang disebarkan kepada peserta untuk mengetahui berapa peserta yang setuju dengan pernyataan bahwa "isi materi pelatihan jelas dan mudah dipahami" maka pada gambar 6 menunjukan terdapat $50 \%$ peserta menyatakan sangat setuju dengan pernyataan ini.

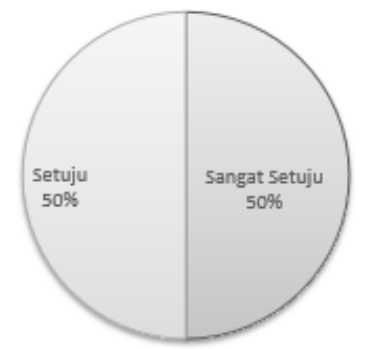

Gambar 6. Hasil Kuesioner Isi Materi Pelatihan Jelas dan Mudah dipahami

2. Instruktur Memberi Kesempatan Kepada Peserta untuk bertanya

Berdasarkan hasil kuesioner yang disebarkan kepada peserta untuk mengetahui berapa peserta yang setuju dengan pernyataan bahwa "Instruktur memberikan kesempatan kepada peserta untuk bertanya" maka pada gambar 7 menunjukan terdapat $63 \%$ peserta menyatakan setuju dengan pernyataan ini.

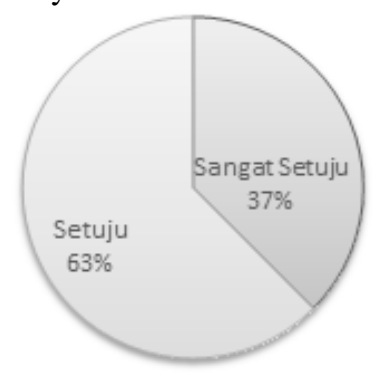

\section{Gambar 7. Hasil Kuesioner Instruktur memberikan} kesempatan bertanya kepada peserta

3. Instruktur menjawab pertanyaan dengan jelas dan mudah dipahami

Berdasarkan hasil kuesioner yang disebarkan kepada peserta untuk mengetahui berapa peserta yang setuju dengan pernyataan bahwa "instruktur menjawab pertanyaan dengan jelas dan mudah dipahami" maka pada gambar 8 menunjukan terdapat $50 \%$ peserta menyatakan sangat setuju dengan pernyataan ini.

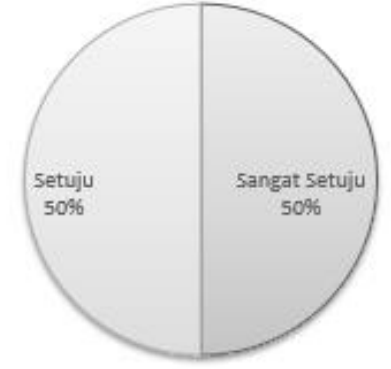

Gambar 8. Hasil Kuesioner Instruktur menjawab pertanyaan dengan jelas dan mudah dipahami

4. Instruktur memberikan contoh latihan dengan jelas dan mudah dipahami

Berdasarkan hasil kuesioner yang disebarkan kepada peserta untuk mengetahui berapa peserta yang setuju dengan pernyataan bahwa "Instruktur memberikan contoh latihan dengan jelas dan mudah dipahami" maka pada gambar 9 menunjukan terdapat $62 \%$ peserta menyatakan sangat setuju dengan pernyataan ini.

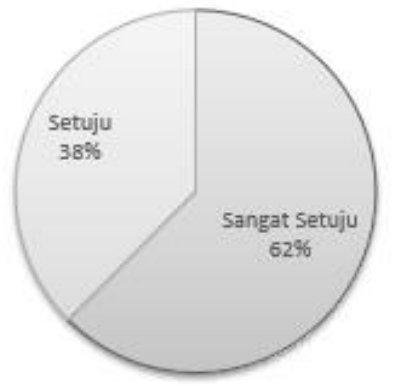

Gambar 9. Hasil Kuesioner Instruktur memberikan contoh latihan dengan jelas dan mudah dipahami

5. Instruktur dan asisten instruktur membantu peserta pelatihan sehingga peserta memahami materi dengan baik

Berdasarkan hasil kuesioner yang disebarkan kepada peserta untuk mengetahui berapa peserta yang setuju dengan pernyataan bahwa "Instruktur dan asisten instruktur membantu peserta pelatihan sehingga peserta memahami materi dengan baik" maka pada gambar 10 menunjukan terdapat $50 \%$ peserta menyatakan setuju dengan pernyataan ini.

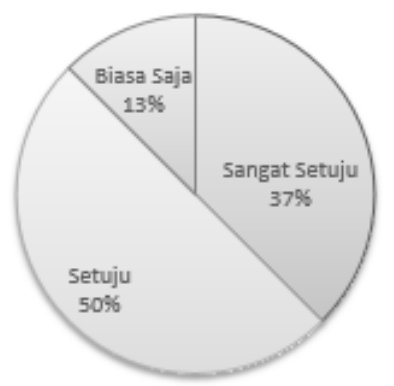

Gambar 10. Hasil Kuesioner Asisten dan instruktur membantu peserta pelatihan 
6. Fasilitas Laboratorium Komputer sesuai dengan kebutuhan pelatihan

Berdasarkan hasil kuesioner yang disebarkan kepada peserta untuk mengetahui berapa peserta yang setuju dengan pernyataan bahwa "Fasilitas laboratorium komputer sesuai dengan kebutuhan pelatihan" maka pada gambar 11 menunjukan $50 \%$ peserta menyatakan sangat setuju dengan pernyataan ini.

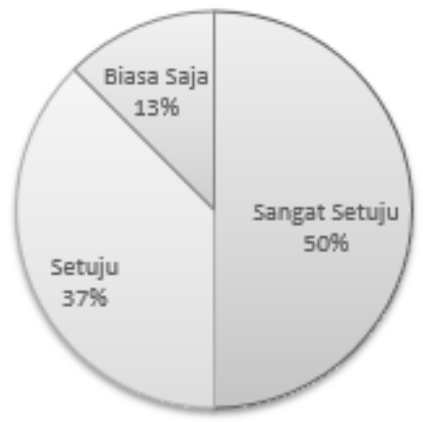

Gambar 11. Hasil Kuesioner Fasilitas Laboratorium Komputer sesuai dengan kebutuhan pelatihan

\section{KESIMPULAN}

Terlaksananya seluruh kegiatan pada program pengabdian kepada masyarakat bekerjasama dengan mitra PKBM Negeri 27 Petukangan menunjukkan bahwa kegiatan Pelatihan penggunaan aplikasi presentasi dengan Microsoft Power Point berjalan dengan baik dan terbukti meningkatkan keterampilan guru di PKBM Negeri 27 Petukangan, ini terlihat dari hasil kuesioner yang menyatakan bahwa $50 \%$ peserta setuju isi materi pelatihan jelas dan mudah dipahami, $62 \%$ peserta sangat setuju contoh latihan jelas dan mudah dipahami, 50\% peserta menyatakan setuju instruktur dan asisten instruktur membantu peserta pelatihan memahami materi dengan baik, $50 \%$ peserta menyatakan sangat setuju fasilitas laboratorium komputer sesuai dengan kebutuhan pelatihan dan secara umum peserta menerima manfaat dengan adanya pelatihan Microsoft Power Point.

\section{SARAN}

Kegiatan Pengabdian Kepada Masyarakat di PKBM Negeri 27 Petukangan diharapkan dapat diadakan pelatihan memanfaatkan google classroom kelas online agar guru dapat berbagi materi pelajaran secara daring dan siswa dapat mengunduh materi yang dibuat oleh guru secara daring.

\section{DAFTAR PUSTAKA}

Fitria and Arfida, S. 2015. IbM untuk Peningkatan Kompetensi Guru dalam Penggunaan Aplikasi Komputer di Bandar Lampung. Jurnal Teknologi Informasi dan Bisnis Pengabdian Masyarakat Darmajaya, 1(2), 83-91.

Harmanto, B. 2015. Merancang Pembelajaran Menyenangkan bagi Generasi Digital. Seminar Nasional Pendidikan (Inovasi Pembelajaran untuk
Pendidikan Berkemajuan). Ponorogo: Fakultas Keguruan dan Ilmu Pendidikan - Universitas Muhammadiyah Ponorogo, 1-6.

Kemdikbud. 2019. Mendikbud Dorong Pengembang Teknologi Pembelajaran Lebih Kreatif dan Inovatif, Kemdikbud.go.id. Available at: https://www.kemdikbud.go.id/main/blog/2019/03/me ndikbud-dorong-pengembang-teknologipembelajaran-lebih-kreatif-dan-inovatif (Accessed: 1 October 2019).

Nahlah, N. et al. 2018. PKM Service For Teachers Group In Improving Their Microsoft Office Skills at SMA NEGERI 10 Makassar. Prosiding Seminar Hasil Pengabdian (SNP2M) 2018. Makassar: Politeknik Negeri Ujung Pandang, 4-9.

Nurhadi, Santoso and Kasijanto. 2018. Peningkatan Kompetensi Mengajar Guru-Guru PAUD di Wilayah Kecamatan Blimbing Kota Malang dengan Pelatihan Komputer dan Multimedia. Jurnal Aplikasi dan Inovasi Ipteks 'SOLIDARITAS', 1(1), 1-8.

Nurrita, T. 2018. Pengembangan Media Pembelajaran Untuk Meningkatkan Hasil Belajar Siswa. Misykat, 3(1), 171-187. Available at: https://media.neliti.com/media/publications/271164pengembangan-media-pembelajaran-untuk-meb2104bd7.pdf.

Sagala, S. 2017. Konsep dan makna pembelajaran : untuk membantu memecahkan problematika belajar dan mengajar. 13th edn. Bandung: Alfabeta.

Sanjaya, W. 2014. Strategi Pembelajaran Berorientasi Standar Proses Pendidikan. 11th edn. Jakarta: Kencana, Prenada Media Grou.

Shedriko, Setiawan, H. S. and Kusmayadi. 2018. Perangkat Lunak PowerPoint Untuk Meningkatkan Kinerja Guru di SD DAN SMP 19 Muhammadiyah Sawangan Depok. Jurnal PKM : Pengabdian Kepada Masyarakat, 1(2), 151-158.

Simanjuntak, P. and Handoko, K. 2019. Pembinaan Pemanfaatan Teknologi Informasi Dan Komunikasi pada Masyarakat Pulau Temoyong Batam Kepulauan Riau. MATAPPA: Jurnal Pengabdian Kepada Masyarakat, 2(1), 20-23.

\section{UCAPAN TERIMA KASIH}

Terima kasih atas dukungan dan sumber pendanaan internal yang diberikan oleh Universitas Budi Luhur pada kegiatan pengabdian kepada masyarakat ini sehingga kegiatan berjalan dengan lancar. 